Психолого-педагогічні проблеми становлення сучасного фахівця Випуск 2018

УДК 37.015.31-047.75:911

DOI 10.26697/9786177089017.2018.233

(C) Саакян Н. А., 2018

Саакян Нарек Апресович

Армянский государственный педагогический университет имени Хачатура Абовяна

\title{
ФОРМИРОВАНИЕ ТВОРЧЕСКОГО МЫШЛЕНИЯ УЧЕНИКОВ КАК ОДНА ИЗ ОСНОВНЫХ ЦЕЛЕЙ ГЕОГРАФИЧЕСКОГО ОБРАЗОВАНИЯ
}

В этой статье рассматриваются вопросы формирования и развития творческого мышления в прочессе географического образования учеников. Основываясь на теоретических и практических исследованиях, отмечается, что уровень обучения географии будет выстим, когда ученики с помощью собственного творческого мышления начнут сами конструировать учебный процесс.

Ключевые слова: творческое мышление, географическое образование, творческая деятельность.

Проблема, её связь с важными научными или практическими задачами. География является одним из тех школьных предметов, который помогает ребенку развиваться, осознавать свою значимость в этом мире, а самооценка и важность человека возрастают, когда тот, самостоятельно или с помощью вмешательства, способен создавать, раскрывать что-то новое. А в этом ученикам помогает их творческое мышление. Творческое мышление один из видов мышления, характеризующийся созданием субъективно нового продукта и новообразованиями в самой познавательной деятельности по его созданию. Эти новообразования касаются мотивации, целей, оценок, смыслов [1].

Мы живем в эпоху глобальной перестройки общества. В педагогике это связано с переходом к новым оптимальным психологопедагогическим системам - креативным технологиям обучения. Социальный заказ на исследование механизмов развития творческого потенциала личности обусловил особую актуальность проблемы формирования творческого мышления.

Анализ публикаций. По этой теме известный психолог Абрахам Маслоу пишет: «Мы должны учить детей быть творческими личностями, способными к восприятию новизны, умению импровизировать. Нам сегодня необходим человек иного качества, который чувствует себя достаточно сильным и отважным, чтобы смело входить в современную ситуацию, уметь владеть проблемой 
творчески, без предварительной подготовки, если это будет нужно. Во времена быстрых перемен дети нуждаются в гибкости и независимости мышления, вере в свои силы и идеи, мужестве пробовать и ошибаться, приспосабливаться и меняться, пока удовлетворительное решение не будет найдено» [2].

Изложение основного материала, обоснование результатов исследования. Основой образовательного процесса является поддержка учителя к формированию творческой личности ученика. Каждый урок должен стать мотивацией для студентов, чтобы проверить их творчество, и формировать в них потребность сформирования в себе творческой личности. Вот почему учитель должен найти методы и формы обучения, чтобы сформировать в учениках творчество. Интересный урок дает детям возможность продемонстрировать свои творческие способности, принять непосредственное участие в процессе обучения материалу урока, благодаря чему материалы урока лучше укрепляются в памяти учеников.

В процессе обучения географии развитие творческого мышления учеников основано на географических знаниях, навыках и способностях, которые получили ученики на уроках. Очень важно, чтобы учитель объяснял практическое значение географических знаний, полученных учениками на каждом уроке. И если после этого учитель задает такие задачи, которые требуют от учащихся творческого подхода, а также показывает применимость полученных теоретических знаний, основываясь на личном жизненном опыте, тогда знание становится основой для создания чего-то нового, а процесс обучения служит своей цели.

Конечной целью учителя должно быть формирование познавательной и творческой деятельности учащихся. Более эффективно, когда учитель создает такие условия, чтобы ученики сами могли развивать свое творческое мышление, учиться приобретать опыт творческой деятельности, а это возможно только в условиях решения проблем творческого обучения.

На уроках географии учитель должен использовать множество подходящих методов, инструментов и средств для формулирования и развития творческого мышления и творческой деятельности учащихся, a также найти эффективные способы их сочетания. С этой целью можно применить богатый методологический набор обучения географии для развития творческого мышления учеников. Среди таких методов отметим: объяснение, описание, составление сравнительной характеристики, задания с использованием контурных карт, проблемное изложение, частично-поисковые, исследовательские, интерактивные методы (мозговой штурм, призма, отображение идей, 
Психолого-педагогічні проблеми становлення сучасного фахівця Випуск 2018

диаграмма Венна, ролевая игра, система взаимодействующих символов, дискуссия, три ключа один замок и т. д.). Но основные методы, которые особо эффективны для развития творческого мышления - это проблемное изложение, частично-поисковые и исследовательские методы, которые в методике обучения географии называют творческими методами, или методами проблемного обучения.

Для применения этих методов учитель, в первую очередь, должен создать проблемную ситуацию. Проблемная ситуация должна создаваться с учетом реальных противоречий, значимых для учащихся. Только в этом случае она является мощным источником мотивации познавательной деятельности школьников, активизирует их мышление, направляет его.

Применению этих методов значительно способствует используемая в учебнике система вопросов и заданий. Часть из них целенаправлена на формирование и решение образовательной проблемы, другая часть является познавательной проблемой, пути решения которой можно частично найти в материалах учебника, а для полного решения необходимо обратиться к другим научным источникам.

Благодаря выполнению работы творческого характера, учащиеся приобретают опыт творческой деятельности. Во время творческой деятельности каждый ученик сам выбирает и создает систему действий. Однако это происходит не автоматически, поэтому учитель должен помочь учащимся овладеть возможностями интеллектуальной деятельности (анализ, синтез, абстракция, сравнение, классификация, обобщение и т. д.). Он также должен развивать их логическое мышление, способствовать формированию познавательного интереса к географии [3, с. 131].

Кроме учителя, решением этих проблем занимаются авторы учебников. Они в начале, в конце текста урока или в тексте задают такие вопросы, которые помогают учащимся логическим, творческим уровнем воспринимать полученные знания. По нашему мнению, процесс формирования и развития творческого мышления был бы более эффективным, если на каждом уроке учитель употреблял бы методы проблемного обучения. Например, в процессе проверки старого урока можно дать контурные карты, и сказать ученикам, чтобы всё, что они помнят из старого урока, отобразили на карте с помощью собственных условных знаков. В этом случае мы создаем проблемную ситуацию для учеников, а основной метод обучения - частичнопоисковый. Еще нужно часто давать детям исследовательские работы, но важно, чтобы эти работы были несложными по выполнению, поскольку такие работы ученики должны выполнять практически на 


\section{Збірник наукових статей}

каждом уроке. Среди домашних заданий, заданных на уроках географии, нужно увеличивать количество таких задач, которые требуют от учащихся частично-поисковую и исследовательскую работу. Следует отметить, что для формирования и развития творческого мышления на уроках географии, кроме этих методов, эффективны еще творческие сочинения, географический танец, интерактивные методы и практические уроки в природе. В эффективности всех этих методов мы убедились во время учебной педагогической практики, при преподавании географии в разных классах. Во время практики сделали некоторые исследования, чтобы понять роль творческого мышления в процессе обучения географии. Для этого мы работали в параллельных классах 7(а) и 7(б). 3 недели подряд мы на уроках в 7(а) употребляли только традиционные методы обучения, а в 7(б) употребили такие методы, которые активируют творческое мышление учеников, в основном методы проблемного обучения. В результате наших исследований стало ясно, что в течение этих 3 недель класс 7(б) лучше освоил все уроки, чем 7(а). Наше исследование выявило важность творческих методов, и с помощью их формирование и развитие творческого мышления учеников.

Выводы. В заключении хочется сказать, что формирование и развитие творческого мышления учеников должно быть одним из основных целей географического образования в школе, поскольку ученик, у которого развито творческое мышление, может сам конструировать учебный процесс, отслеживать направления своего развития и, в конце концов, может сам определять конечный результат.

\section{Литература}

1. Творческое мышление, развитие креативности [Электронный pecypc]. - Режим доступа : https://4brain.ru/tvorcheskoe-myshlenie/.

2. Развитие творческих способностей учащихся на уроках географии через использование технологии проблемного обучения в 8 классе [Электронный ресурс]. - Режим доступа : https://kopilkaurokov.ru/geografiya/prochee/ razvitiie-tvorchieskikhsposobnostiei-uchashchikhsia-na-urokakh-ghieoghrafii-chieriez-ispolzovaniie-tiekhnologhii-probliemnogho-obuchieniia-v-8-klassie.

3. Минасян А. А. Методика обучения географии А. А. Минасян. - Ер., 2013. - 344 с. (на армянском языке). 
Психолого-педагогічні проблеми становлення сучасного фахівця Випуск 2018

Нарек Саакян. Формування творчого мислення учнів як одна з основних цілей географічної освіти.

У иій статті розглядаються питання формування $i$ розвитку творчого мислення в прочесі географічної освіти учнів. Грунтуючись на теоретичних і практичних дослідженнях, відзначається, щуо рівень навчання географії буде вищим, коли учні за допомогою власного творчого мислення почнуть самі конструювати навчальний процес.

Ключові слова: творче мислення, географічна освіта, творча діяльність.

Narek Sahakyan. The formation of learners' creative thinking as one of the main objectives of geographical education.

This article deals with the formation and development of creative thinking in the process of geographic education of students. Based on theoretical and practical researches, it is said that the level of teaching geography will be higher when students with their own creative thinking will begin to design the learning process.

Keywords: creative thinking, geographical education, creative activity.

Стаття надійшла до редакційної колегії 05.05.2018

Прийнято до друку 09.05.2018

Информация об авторе:

Саакян Нарек Апресович - Армянский государственный педагогический университет имени Хачатура Абовяна. 